\title{
LYST Gene
}

National Cancer Institute

\section{Source}

National Cancer Institute. LYST Gene. NCI Thesaurus. Code C24298.

This gene plays a role in lysosomal protein trafficking and mutations in the gene cause

Chediak-Higashi syndrome. 